\title{
Latent Infection by Clavibacter sepedonicus and Correlation with Ring Rot Symptoms Development in Potato Cultivars
}

\author{
G. Gryń ${ }^{1}$ (D) K. Franke ${ }^{1}$ - M. M. Nowakowski ${ }^{1} \cdot$ M. Nowakowski $^{1}$
}

\begin{abstract}
The aim of this study was to determine the response of potato cultivars to Clavibacter sepedonicus (Cs) infection in a field experiment. The research focused on the infection in a latent form as it is a risk for unnoticed spread. A total of 18 cultivars were tested in the years 2013-2016. Symptoms of the disease were observed on the leaves during growth and in tubers after harvest and after storage. The infection incidence was determined by microscopic observation of leaf and tuber samples stained by the IFAS method. A diverse response of potato cultivars to Cs infection was found. The lowest number of asymptomatic infected plants was found in cultivars 'Vineta', 'Bila' and 'Irga'. As for cultivar 'Stasia', the entire tuber yield was latently infected by Cs. A low or medium concentration of Cs cells in leaves did not change significantly or increased depending on the potato cultivar. A higher incidence of tubers with disease symptoms was found after the storage period. In eight of the cultivars tested, the level of tuber infection by Cs confirmed microscopically after harvest was significantly correlated with the occurrence of disease symptoms in tubers after the storage period.
\end{abstract}

Keywords Bacterial ring rot of potato $\cdot$ Clavibacter sepedonicus $\cdot$ Latent infection

\section{Introduction}

Gram-positive Clavibacter sepedonicus (Cs) (formerly Clavibacter michiganensis ssp. sepedonicus; Li et al. 2018) is the causative agent of potato ring rot. The species has the status of a quarantine organism in the European Union. Council Directive 2006/56/ EC (2006) provides legal regulations regarding detection and control of the pest. The pathogen can be found on all continents where potatoes are grown, except in Australia.

G. Gryń

g.gryn@ihar.bydgoszcz.pl

1 Plant Breeding and Acclimatization Institute-National Research Institute, Division in Bydgoszcz, Bydgoszcz, Poland 
Cs mainly prefers a temperate climate (Hukkanen et al. 2005). The occurrence of Cs bacteria in potato cultivation results in a significant yield decrease and enforces the use of expensive procedures related to the introduction of quarantine at the potato production site. Detection in the field is hampered by a slow development of the disease due to a low multiplication rate. Other diseases, nutrient deficiency and drought can mask the expression of symptoms and/or result in symptoms similar to those of ring rot. Typical disease symptoms appear at a later stage of plant growth in the form of chlorosis among the leaf vascular bundles, leading to wilting and necrosis. The Cs infection is most common in the latent form. Standard pathogen detection methods include Gram staining of bacteria, biotests, isolation on semi-selective media and serological and molecular methods (De Boer et al. 2005). The occurrence of disease symptoms depends on potato resistance factors, environmental conditions (temperature, soil conditions and sunlight) and virulence and abundance of Cs bacteria in the plant (Omelichkina et al. 2017; Pánková et al. 2019). Colonization of vascular bundles of a potato plant is associated with several virulence factors of the pathogen. One of those factors is the ability of Cs to form a biofilm (Donlan 2002; van der Wolf et al. 2005; Bae et al. 2014). Current knowledge about the plant-pathogen interaction is insufficient in view of the susceptibility of various potato cultivars to biofilm formation by Cs (Marques et al. 2003). Early detection during plant growth and the differences in disease symptoms among currently grown cultivars are of great importance for the potato industry (Whitworth et al. 2019). The sources of the latent form of the disease, as well as the biotic and abiotic conditions that cause the occurrence of symptoms, have not yet been specified in detail.

The aim of this study was to analyse the susceptibility of selected potato cultivars to Cs infection and to determine the correlation between the density of bacteria in the plant (the number of Cs bacteria cells in $1 \mathrm{ml}$ of plant extract) and the occurrence of disease symptoms in tubers.

\section{Materials and Methods}

The field experiments were performed in the years 2013-2016 at the Institute of Plant Breeding and Acclimatization - National Research Institute, Bydgoszcz, Poland. Tuber yield was analysed twice every year: first in autumn after harvesting and the second time in spring after storage period. The last analysis was performed in spring 2017. A total of 18 potato cultivars, most often cultivated in Poland, were included. A 3-year study was performed for each cultivar, except for 'Innovator' (2-year study). Certified potato tubers free from infection with Cs were used. The study used the NCPPB 4053 mucoid strain with a cell concentration of $2.5 \times 10^{8} \mathrm{cfu} \mathrm{m}^{-1}(0.01 \mathrm{M}$ phosphate buffer, $\mathrm{pH}$ 7.2). Inoculation consisted of introducing a suspension of Cs bacteria or PB buffer alone (negative control) into the tuber through $1 \mathrm{~cm}$ deep incisions, with a sharppointed scalpel with a $4 \mathrm{~cm}$ cutting edge. Each year, 10 tubers were inoculated with the Cs suspension. Another five tubers were used as the control. Tubers were planted in the experimental plots immediately after inoculation at $40 \mathrm{~cm}$ intervals in the rows, with a distance of $70 \mathrm{~cm}$ between rows. Control and inoculated tubers of the same cultivar in two independent experimental plots with $80 \mathrm{~cm}$ distance were planted. The distance between the cultivars was $140 \mathrm{~cm}$. To minimize side effects between and around 
experimental plots, healthy tubers were planted. Tubers were planted into luvisol with a granulometric composition of light loamy sand. The soil was slightly acidic ( $\mathrm{pH} 6.2-$ 6.5), with a high content of phosphorus, potassium and magnesium. Standard fertilization was applied before potato cultivation. During plant growth, protection against Colorado beetle and fungal diseases was performed. The plants were not irrigated. Weeding was carried out manually. A simplified, 2-year crop rotation was introduced in potato cultivation. During growth, after flowering, three leaves from each stem, without disease symptoms, were collected for laboratory tests. During the growth period, screening for ring rot symptoms was performed by analysing the differences in the habit of inoculated and control plants (growth, number of shoots) and typical symptoms on the leaves, i.e. asymmetry, chlorosis and necrosis (Table 2). The tubers were harvested manually, separately from each plant. The harvested tubers were counted and weighed. Tubers were cut using sterile knives to detect infection by a symptomatic form of the disease. If symptoms were found in tubers, no material for microscopic analysis was taken from them. A small core of tissue was cut out by scalpel with blade no. 10 from the stolon end of each symptomless tuber. Healthy leaves from lower level of each stem (20 pieces) and all progeny tubers collected from one plant constituted a single sample. After harvest and sampling in autumn, tubers were stored in a room with temperature set at $4{ }^{\circ} \mathrm{C}$ (winter) for 5 months. Next, they were cut, and symptoms of the infection were again observed.

The Indirect Immunofluorescence Assay (IFAS) was used to assess the density of bacteria in the material collected from the above-ground plant parts and tubers following the Council Directive 2006/56/EC. The petioles were cut by sterile scalpel (blade no. 10) into sections of about $5 \mathrm{~mm}$. Tuber fragments from the heel were cut into cones with a base diameter of about $6 \mathrm{~mm}$. Samples taken from above-ground parts and tubers were shaken in sterile plastic containers in 10 and $5 \mathrm{ml}$ maceration buffer $(0.05 \mathrm{M}$ phosphate buffer, $\mathrm{pH} 7.0)$, respectively, for $4 \mathrm{~h}$. The suspension was then centrifuged $(10,000 \mathrm{rpm}$, $10 \mathrm{~min}, 4^{\circ} \mathrm{C}$ ). The supernatant was gently decanted, and the concentrated pellet was suspended in $1 \mathrm{ml}$ of $0.01 \mathrm{M}$ phosphate buffer ( $\mathrm{pH} 7.2$ ). The sample, as well as its 10and 100-fold dilutions, was applied to multi-point slides (Thermo Scientific, 10 well, $6.7 \mathrm{~mm})$, dried on a heating plate $\left(37^{\circ} \mathrm{C}\right)$ and fixed over a flame. Polyclonal antibodies (Loewe Biochemica $\mathrm{GmbH}$ ) and conjugate (Loewe Biochemica $\mathrm{GmbH},-\mathrm{Cy} 3$ ) were used for staining. Staining with a monoclonal antibody kit (Agdia) was used to confirm the uncertain samples in which atypical cells due to cross-reaction were observed. Observation was performed at $\times 1000$ magnification (Nikon Eclipse Ci), by counting typical bacterial cells in 40 fields of vision of the microscope.

\section{Statistical Analysis}

In order to facilitate the analysis, the results of microscopic observations are presented as levels (degrees) of infection, corresponding to the mean number of Cs bacteria cells in the microscope field of vision and the number of Cs bacterial cells in $1 \mathrm{ml}$ of plant extract (Table 1). Leaf extracts (from leaf petioles) and cones cut with a scalpel from the heel end of tubers from Cs-free plants as described above were used to prepare the infection scale. The amount of plant material used corresponded to the mean number of petioles and tuber cones in the plot experiment. Suspensions of Cs bacteria with a known number of cells in $1 \mathrm{ml}$ were added to the extracts, shaken for $30 \mathrm{~min}$ and 
Table 1 Scale of tuber latent infestation by Cs, based on the IF test

\begin{tabular}{llll}
$\begin{array}{l}\text { Level of } \\
\text { infection }\end{array}$ & $\begin{array}{l}\text { Number of Cs cells observed in the } \\
\text { microscope field of vision }\end{array}$ & $\begin{array}{l}\text { Mean number of Cs cells in } 1 \mathrm{ml} \text { of } \\
\text { petiole extract and heel tuber fragments }\end{array}$ & $\begin{array}{l}\text { Number of Cs } \\
\text { cells in the plant }\end{array}$ \\
\hline 1 & $0-20$ in the preparation well & $\begin{array}{l}<1.9 \times 10^{4} \\
2.0 \times 10^{4}-1.9 \times 10^{6}\end{array}$ & Low \\
2 & $0-5$ & & Medium \\
3 & $6-10$ & $2.0 \times 10^{6}-6.9 \times 10^{7}$ & High \\
4 & $11-25$ & & \\
5 & $26-75$ & & \\
6 & $76-150$ & $7.0 \times 10^{7}-4.9 \times 10^{8}$ & Very high \\
7 & $151-300$ & & \\
8 & $301-500$ & $>5.0 \times 10^{8}$ &
\end{tabular}

placed on microscope slides. After fixation, the specimens were stained with a polyclonal antibody kit. The counting results from 40 fields of vision were used to calculate the mean number of cells in the field of vision of the microscope. Table 1 presents the mean number of bacteria in leaf and tuber samples.

The following parameters are given: the incidence (\%) of tubers infected with the symptomatic form of the disease after the growing season, the incidence of rotten tubers (the severity of other diseases might have been the result of infection with ring rot) and the incidence of tubers with symptoms observed in spring after storage. Tuber samples with confirmed homogenization of vascular bundle in autumn and after storage were compared with the results of microscopic observations of these samples. The obtained results of latent infection allowed for the division of cultivars based on the expression of disease symptoms and bacterial cell content in leaves and yield. The yield of control and inoculated plants within a given cultivar was compared with Student's $t$ test for independent samples. A non-parametric Spearman correlation was calculated between the content of bacteria in tubers (expressed as the level of infection) and the content of bacteria in leaves, the number of tubers with symptoms after the growing season and after storage. All statistical analyses were performed using the Statistica 8.0 software.

\section{Results}

Symptoms on plants during growth are difficult to observe. Among the tested plants, only 10 cultivars showed typical symptoms on the leaves. In the years 2014-2015, differences in the growth of inoculated and Cs-free plants were reported in seven cultivars (Table 2). The presence of a latent form of the disease was confirmed microscopically in all cultivars tested, with various numbers of infected plants. Analysing the average plant infection in different growth periods, a higher incidence of samples containing Cs was found in progeny tubers than in leaves (except in the year 2014). The least asymptomatically infected plants were found in cultivars 'Vineta', 'Bila' and 'Irga'. As for cultivar 'Stasia', the entire studied tuber yield (years 2013, 2014, 2016) was latently infected by Cs. A very high incidence of samples from progeny tubers latently infected by Cs was found in cultivars 'Cekin', 'Michalina' and 'Owacja'. 
Table 2 Observations of ring rot on plants during the growing season and the share (\%) of samples from leaves and tubers infected latently by $\mathrm{Cs}$ in the IFAS test

\begin{tabular}{|c|c|c|c|c|c|c|c|c|c|}
\hline \multirow[t]{2}{*}{ Cultivar } & \multicolumn{4}{|c|}{ 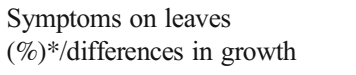 } & \multicolumn{5}{|c|}{$\begin{array}{l}\text { Incidence of samples latently infected by Cs based on } \\
\text { leaf/tuber IFAS }\end{array}$} \\
\hline & 2013 & 2014 & 2015 & 2016 & 2013 & 2014 & 2015 & 2016 & 2013-2016 \\
\hline Bellarosa & nt & $10 /+$ & - & - & nt & $60 / 70$ & $40 / 90$ & $80 / 100$ & $60 / 87$ \\
\hline Berber & - & - & nt & - & $90 / 67$ & $90 / 100$ & $\mathrm{nt}$ & $70 / 90$ & $83 / 86$ \\
\hline Bila & $\mathrm{nt}$ & $-/+$ & 10 & - & $\mathrm{nt}$ & $10 / 80$ & $80 / 60$ & $90 / 80$ & $60 / 73$ \\
\hline Bryza & $\mathrm{nt}$ & - & - & - & $\mathrm{nt}$ & $29 / 90$ & $80 / 90$ & $90 / 100$ & $66 / 93$ \\
\hline Cekin & nt & $-1+$ & $20 /+$ & 10 & nt & $78 / 89$ & $80 / 100$ & $90 / 100$ & $83 / 96$ \\
\hline Denar & $\mathrm{nt}$ & $-/+$ & 10 & 30 & $\mathrm{nt}$ & $100 / 100$ & $50 / 100$ & $60 / 70$ & $70 / 90$ \\
\hline Ingrid & - & - & $\mathrm{nt}$ & - & $100 / 100$ & $60 / 90$ & nt & $40 / 80$ & $67 / 90$ \\
\hline Innovator & $\mathrm{nt}$ & $\mathrm{nt}$ & - & - & $\mathrm{nt}$ & $\mathrm{nt}$ & $90 / 100$ & $80 / 70$ & $85 / 85$ \\
\hline Irga & $\mathrm{nt}$ & $-/+$ & $-1+$ & 10 & $\mathrm{nt}$ & $40 / 90$ & $78 / 70$ & $80 / 70$ & $66 / 77$ \\
\hline Irys & $\mathrm{nt}$ & - & $40 /+$ & - & $\mathrm{nt}$ & $100 / 90$ & $40 / 100$ & $90 / 90$ & $77 / 93$ \\
\hline Legenda & 10 & $-/+$ & $\mathrm{nt}$ & - & $90 / 100$ & $90 / 70$ & $\mathrm{nt}$ & $90 / 100$ & $90 / 90$ \\
\hline Lord & $\mathrm{nt}$ & - & - & - & $\mathrm{nt}$ & $90 / 70$ & $50 / 100$ & $100 / 50$ & $80 / 73$ \\
\hline Michalina & 10 & - & $\mathrm{nt}$ & 10 & $90 / 100$ & $60 / 100$ & $\mathrm{nt}$ & $70 / 90$ & $73 / 97$ \\
\hline Miłek & - & $-/+$ & $\mathrm{nt}$ & 20 & $100 / 100$ & $90 / 100$ & $\mathrm{nt}$ & $70 / 60$ & $87 / 87$ \\
\hline Owacja & - & - & - & $\mathrm{nt}$ & $100 / 100$ & $90 / 90$ & $100 / 100$ & $\mathrm{nt}$ & $97 / 97$ \\
\hline Stasia & 10 & - & $\mathrm{nt}$ & - & $90 / 100$ & $40 / 100$ & nt & $80 / 100$ & $70 / 100$ \\
\hline Tajfun & $\mathrm{nt}$ & - & - & - & $\mathrm{nt}$ & $60 / 90$ & $80 / 90$ & $90 / 100$ & $77 / 93$ \\
\hline Vineta & $\mathrm{nt}$ & - & - & - & $\mathrm{nt}$ & $70 / 30$ & $50 / 60$ & $60 / 70$ & $60 / 53$ \\
\hline Average & - & - & - & - & $94 / 95$ & $86 / 85$ & $68 / 88$ & $78 / 83$ & - \\
\hline
\end{tabular}

nt, not tested; -, no differences in growth were observed; +, differences in growth were observed; *, incidence of plants with symptoms (asymmetry, chlorosis, wilting, leaf necrosis)

Low correlations were found between the mean level of infection in tuber samples and the mean level of infection in leaf samples for individual potato cultivars (Table 3). Nonetheless, in half of the cultivars tested, a significant decrease in the tuber yield was reported in inoculated plants compared with Cs-free plants. The ratio of yield weight in inoculated plants to that in healthy plants was different in the cultivars tested and ranged from 47.1 to $96.1 \%$.

Individual tubers with symptoms of infection were found both in cultivars with a significant yield decrease ('Bryza', 'Cekin', 'Denar', 'Irga', 'Miłek', 'Owacja', 'Tajfun') and in cultivars with no clear downward trend in tuber yield ('Bellarosa', 'Michalina', 'Vineta'). As for cultivars 'Innovator' and 'Iris', despite the decrease in yield, no symptomatic form of the disease in tubers was found. A much higher incidence of tubers with disease symptoms was found after storage; the mean incidence of tubers with symptoms increased from 0.8 to $4.6 \%$. The increase in the number of tubers with symptoms observed after storage, expressed as a percentage, was proportional to the level of tuber infection. In eight cultivars, the correlation was statistically significant. The mean level of infection in tubers with confirmed symptoms was 6.9 and 7.9 in autumn and after storage, respectively. The level of infection in tubers with confirmed symptoms immediately after harvest ranged from 


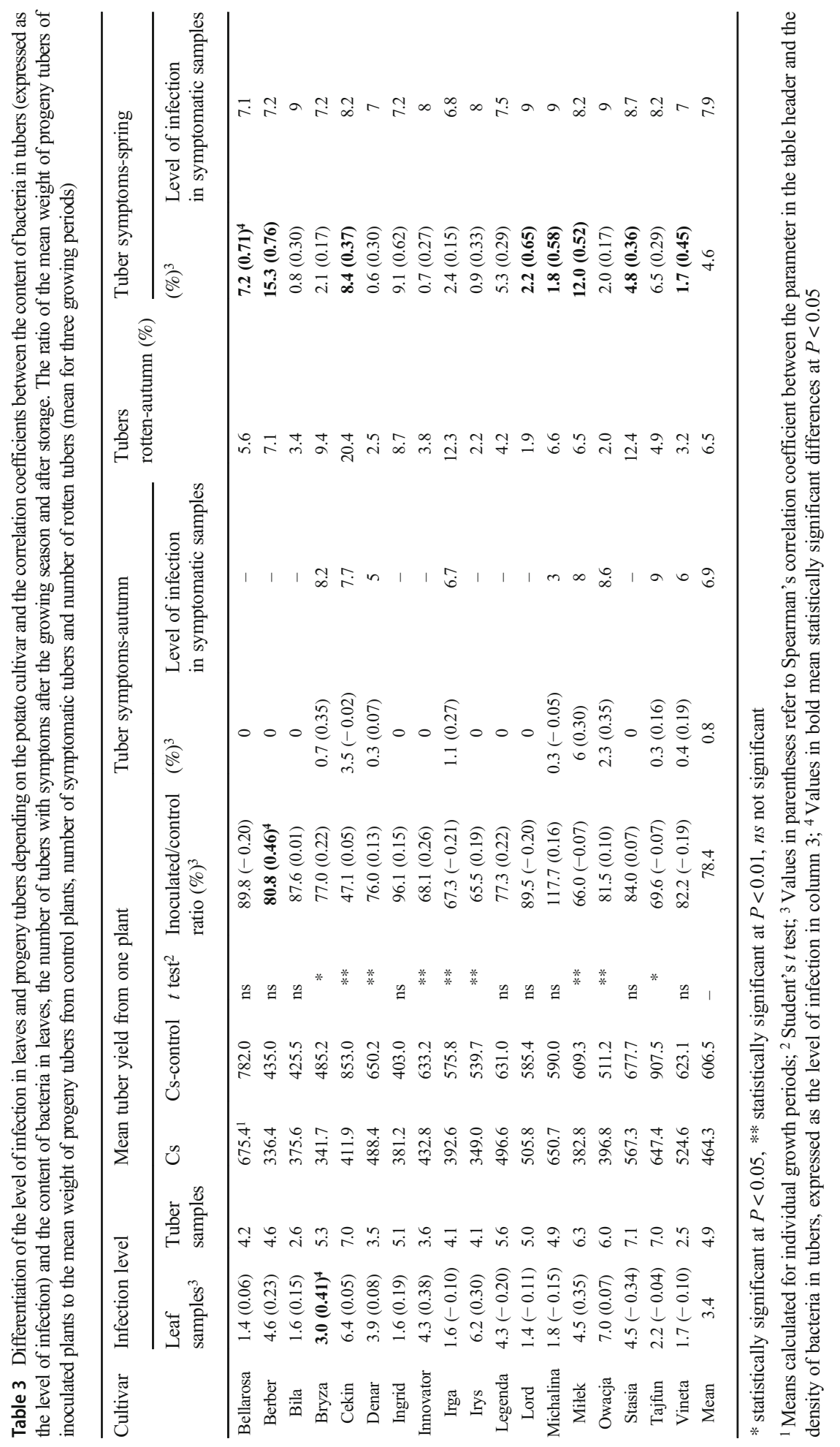


3 ('Michalina') to 9 ('Tajfun'). As for the tuber samples with symptoms found after storage, the level of infection by $\mathrm{Cs}$ was high and ranged from 6.8 to 9 . The incidence of rotten tubers varied in the cultivars tested. More rotten tubers were found in samples with a higher content of Cs cells and a higher incidence of symptomatic tubers.

\section{Discussion}

Introduction of the seed certification programme, the principles of phytosanitary measures and conducted controls has resulted in substantial reduction of the incidence of potato ring rot in many EU countries. According to Hill et al. (2011), information on the symptom expression as well as level of infection, depending on the cultivar and weather conditions, would be important considering the scale of annually performed inspections and the volume of sampling. Research has shown that the cultivar has a significant impact on the level of infection, expression of symptoms and yield decrease. According to Whitworth et al. (2019), knowledge about the type of symptoms and the time of their occurrence on potato plants of new cultivars is important for the producers and manufacturers.

The absence of Cs cells in certified seed material does not mean that there will be no positive samples in commercial production (Kudela 2007). According to Pánková et al. (2019), the occurrence of samples infected by Cs in fields where all procedures have been followed to prevent the spread of the pathogen prompts the need to undertake tests determining the sensitivity and expression of disease symptoms in cultivated potato. According to the authors, data on susceptibility to Cs among cultivated genotypes should also constitute a breeding element. It is generally believed that tolerant cultivars that do not show disease symptoms on the plant and tubers are considered to be a dangerous source of the spread of the disease. According to Pastuszewska (2008) and Franc (1999), disease symptoms may not be found on plants for several seasons of vegetative reproduction in a given cultivar due to low bacterial cell concentration in the plant. Currently, commonly used methods of detecting the culprit of potato ring rot (immunofluorescence test, semi-selective culture and biotest) are not fully effective and according to van Vaerenbergh et al. (2017) should be replaced by more sensitive protocols, especially in the presence of bacteria in the plant at a very low level. In the absence of reliable methods for detection of a latent form of infection by Cs, it is recommended to grow potato cultivars that show the frequent occurrence of typical symptoms of the disease (Manzer et al. 1987; De Bore and McCann 1990).

Due to the choice of a field experiment to evaluate the susceptibility of cultivars to Cs potato infection, we focused mainly on the microscopic assessment of the number of bacteria during growth and in tubers. Macroscopic observation of tubers after harvest and storage was also included. In the present research, a detailed assessment of plant infection during growth was omitted due to different weather conditions and pressure from other pathogens and pests in a given year. In contrast with the research by Whitworth et al. (2019), in the present study, a single dose of bacterial inoculum was used, and plant fragments during growth (after flowering) and after harvest were analysed. In the present study, the number of disease symptoms on leaves and stems was low. Pánková et al. (2019) found that among 52 potato cultivars tested, only 10 (19.2\%) did not show typical changes on the leaves and tubers. The remaining 42 cultivars presented the expression of potato ring rot symptoms with different intensities 
and from time since the moment of inoculation. In the present study, typical lesions were found only in 20 specimens of 10 cultivars. Differences in plant growth were found in the same cultivars, except for 'Bellarosa', 'Michalina' and 'Stasia'. The results of a multi-year study by Hill et al. (2011) are in agreement with the present findings that the symptoms on the plant during growth occur at a constant level in a given cultivar. Research on potato plants representing four cultivars, i.e. 'Cekin', 'Denar', 'Irga' and 'Michalina', showed expression of disease symptoms or changes in growth in two of the three growth periods studied. However, most cultivars showed no signs of infection or only during one growing season. This is in contrast with the reports by Westra and Slack (1994) and Kawchuk et al. (1998) who found that the occurrence and severity of symptoms in tubers were relatively low compared with the symptoms of ring rot on leaves. In the present study, differences in plant habit recorded during growth in 5 out of 7 cases resulted in a significant yield decrease $(P<0.01)$. No signs of disease on the surface of the tubers in the form of cracks in the skin were found, as reported by Whitworth et al. (2019). It should be emphasized that the above studies were conducted on other cultivars, and a different strain and concentration of Cs was used as the inoculum. Analysis of symptoms in tubers made after harvest (autumn), during 4 years of research, revealed a total of 40 tubers with typical changes in vascular bundles. According to Kaemmerer et al. (2007), the size of bacterial population in the aboveground parts and tubers of plants is a factor affecting the occurrence of infection, symptom expression and potato yield. These researchers found that the symptoms appear on leaves and in progeny tubers only with a higher bacterial concentration in the plant. In the present study, the tested cultivars were characterized by a different number of bacterial cells in samples from the above-ground parts and from tubers. One should keep in mind that the Cs biofilm formation is local and uneven in the plant. The lack of correlation between the content of Cs cells and the occurrence of symptoms may be caused by difficulties in the research methodology. Based on the study, the cultivars were divided into genotypes with low or medium cell concentration in leaves and tubers ('Bila', 'Denar', 'Vineta') and with low or medium cell concentration in leaves and high in tuber samples ('Bellarosa', 'Bryza', 'Ingrid', 'Irga', 'Lord', 'Michalina', 'Tajfun'). Other cultivars were characterized by a high level of leaf and tuber infection (except for 'Innovator'-medium level of cell concentration in tubers). Kaemmerer et al. (2007) also reported that $20 \%$ of tubers derived from plants with higher infection and stored for 4 months showed typical disease symptoms. The number of bacteria detected with the IFAS test in tuber samples stored until spring did not change significantly. In the present study, a significant increase in the number of tubers with symptoms was found after 5 months of storage. Due to the methodology used, the number of bacteria in tubers stored during winter was not microscopically evaluated. However, it was found that in eight cultivars, a low incidence of tubers with symptoms occurred both after harvest and after storage. In six cultivars studied, infections in none or a small number of post-harvest tubers increased significantly after storage. Two cultivars, 'Cekin' and 'Miłek', showed a high incidence of tubers with symptoms immediately after harvest and in spring.

In conclusion, a varied response of potato cultivars to latent and symptomatic infection by potato ring rot was observed. The number of bacteria in a plant that causes the disease to change from asymptomatic to symptomatic form varies depending on the potato cultivar. Therefore, it is important to recognize factors other than the number of 
bacteria in the plant and their virulence that determine the reaction of cultivars to Cs infection (e.g. habitat and weather conditions).

Open Access This article is licensed under a Creative Commons Attribution 4.0 International License, which permits use, sharing, adaptation, distribution and reproduction in any medium or format, as long as you give appropriate credit to the original author(s) and the source, provide a link to the Creative Commons licence, and indicate if changes were made. The images or other third party material in this article are included in the article's Creative Commons licence, unless indicated otherwise in a credit line to the material. If material is not included in the article's Creative Commons licence and your intended use is not permitted by statutory regulation or exceeds the permitted use, you will need to obtain permission directly from the copyright holder. To view a copy of this licence, visit http://creativecommons.org/licenses/by/4.0/.

\section{References}

Bae YM, Zheng L, Hyun JE, Jung KS, Heu S, Lee SY (2014) Growth characteristics and biofilm formation of various spoilage bacteria isolated from fresh produce. J Food Sci 79(10):M2072-M2080

Council directive 2006/56/EC (n.d.) Off J Eur Commun L 182:1-43

De Boer SH, McCann M (1990) Detection of Corynebacterium sepedonicum in potato cultivars with different propensities to express ring rot symptoms. Am J Potato Res 67:685-694

De Boer SH, Charkowski AO, Zink RT, Martinez-Soriano JP, Flores-Olivas A (2005) Procedure for detection and identification of Clavibacter michiganensis subsp. sepedonicus (Spieckermann and Kotthoff) Davis, Gillaspie, Vidaver and Harris, in potato (Solanum tuberosum L.) tubers. Rev Mex Fitopatol 23:329-334

Donlan RM (2002) Biofilms: microbial life on surfaces. Emerg Infect Dis 8(9):881-890

Franc GD (1999) Persistence and latency of Clavibacter michiganensis subsp. sepedonicus in field-grown seed potatoes. Plant Dis 83:247-250

Hill BD, Kalischuk M, Waterer DR, Bizimungu B, Howard R, Kawchuk LM (2011) An environmental model predicting bacterial ring rot symptom expression. Am J Potato Res 88:294-301

Hukkanen A, Karjalainen R, Nielsen S, van der Wolf JM (2005) Epidemiology of Clavibacter michiganensis subsp. sepedonicus in potato under European conditions: population development and yield reduction. J Plant Dis Protect 112(1):88-97

Kaemmerer D, Seigener L, Poschenrieder G, Zellner M, Munzert M (2007) Epidemiology of bacterial ring rot of potato in plant and soil - consequences for disease management. J Plant Dis Protect 114(4):159-166

Kawchuk LM, Lynch DR, Kozub GC, Nelson GA, Kulcsar F, Fujimoto DK (1998) Multi-year evaluation of Clavibacter michiganensis subsp. sepedonicus disease symptoms in cultivated potato genotypes. Am J Potato Res 75:235-243

Kudela V (2007) History of bacterial ring rot of potato in the Czech landsand a proposal for relaxation of strict quarantine measures. Plant Protect Sci 43:35-46

Li X, Tambong J, Yuan KX, Chen W, Xu H, Lévesque C, De Boer SH (2018) Re-classification of Clavibacter michiganensis sub-species on the basis of whole-genome and multi-locus sequence analyses. Int J Syst Evol Microbiol 68:234-240

Manzer FE, Gudmestad NC, Nelson GA (1987) Factors affecting infection, disease development and symptom expression of bacterial ring rot. Am J Potato Res 64:641-676

Marques LLR, de Boer SH, Ceri H, Olson ME (2003) Evaluation of biofilms formed by Clavibacter michiganensis subsp. sepedonicus. (Abstr.). Phytopathology 93:S57

Omelichkina YV, Boyarkina SV, Shafikova TN (2017) Effector-activated immune responses in potato and tobacco cell cultures caused by phytopathogen Clavibacter michiganensis ssp. sepedonicus. Russ J Plant Physiol 64(3):423-430

Pánková I, Krejzar V, Krejzarová R (2019) Categorisation of reactions and enumeration of bacteria in potato cultivars inoculated with the causal agent of bacterial ring rot. Plant Protect Sci 55:11-22

Pastuszewska T (2008) Development rate of bacterial ring rot infection in progeny tubers of potato. Adv Agric Sci Problem Issues 531:161-168 (In Polish)

Van der Wolf JM, Elphinstone JG, Stead DE, Metzler M, Müller P, Hukkanen A, Karjalainen R (2005) Epidemiology of Clavibacter michiganensis subsp. sepedonicus in relation to control of bacterial ring rot, February 2005. Report 95:3-21. Plant Research International, Wageningen 
van Vaerenbergh J, Müller P, Elphinstone JG, Vreeburg RAM, Janse JD (2017) Euphresco inter-laboratory comparison (2009-2012) on detection of Clavibacter michiganensis subsp. sepedonicus and Ralstonia solanacearum in potato tubers: proposal to include TaqMan real-time PCR as a primary (core) screening test in EU/EPPO standard methods. Bull OEPP/EPPO Bull 47(1):24-32

Westra AAG, Slack SA (1994) Effect of interaction of inoculum dose, cultivar, and geographic location on the magnitude of bacterial ring rot symptoms expression in potato. Phytopathology 84:228-235

Whitworth JL, Selstedt RA, Westra AAG, Nolte P, Duellman K, Yellareddygari SKR, Gudmestad NC (2019) Symptom expression of mainstream and specialty potato cultivars to bacterial ring root (Clavibacter sepedonicus) and evaluation of in-field detection. Am J Potato Res 96(4):427-444

Publisher's Note Springer Nature remains neutral with regard to jurisdictional claims in published maps and institutional affiliations. 